phytosanitary measures applicable to trade, approximation of the laws of Ukraine to those of the EU, acceptance of the animal and plant health of the Parties and the application of the principle of regionalization, establishing a mechanism pattern for recognizing equivalency in sanitary and phytosanitary measures. The biggest part of Ukraine's commitments under the Association Agreement with the EU relates to the adoption of EU regulations in the agricultural sector. They can be grouped into three blocks, namely: technical requirements - requirements for product safety, technical standardization, packaging and product labeling, sanitary and phytosanitary requirements relate to the safety of food and feed, protection of health and safety of humans, animals and plants; environmental requirements - requirements and regulations for the import into EU of fertilizers, plant protection products, endangered animal species, waste from the agricultural sector agriculture.

Key words: sanitary and phytosanitary requirements, Association Agreement with the EU,

УДК 347.63:347.44]:347.961

DOI https://doi.org/10.32782/2409-4544/2019-2/14

Ю. Левчук

\title{
Теоретичні та практичні аспекти нотаріального посвідчення договору про надання послуг сурогатного материнства
}

У статті висвітлено основні аспекти нотаріального посвідчення договорів про надання послуг сурогатного материнства в практичній площині, а також проаналізовано теоретичні основи законодавчого регулювання процесу укладення договору про надання послуг сурогатного материнства в Україні. Регулювання сурогату має цивільно-правовий характер. Сурогатне материнство покликане регулювати відносини між біологічними батьками та сурогатною матір'ю, зокрема шляхом укладення цивільно-правового договору. У договорі про надання послуг сурогатного материнства необхідно передбачити всі можливі варіанти розвитку подій з метою забезпечення безспірності подальших відносин. Тому в ньому необхідно обов'язково прописувати чіткий предмет договору та чіткий розмір компенсацій сурогатної матері за виношування і народження нею дитини (крім випадків безкоштовності такого договору за бажанням сторін); права, обов'язки та відповідальність сторін договору; порядок припинення, відмови від договору; інші істотні умови. Нагальним $\epsilon$ врегулювання процедури нотаріального посвідчення договору про надання послуг сурогатного материнства на рівні профільного закону з чітким встановленням вимог до його учасників та, власне, й самого договору. В силу відсутності в нашому законодавстві детальної регламентації процедури сурогатного материнства та профільного закону, залишається плекати надію на нотаріально посвідчений договір між батьками-замовниками сурогатної програми та сурогатною матір'ю, як на такий, що не допустить виникнення конфліктних та спірних ситуацій та полегшить процес врегулювання відносин між потенційними батьками та сурогатною матір'ю.

Ключові слова: сурогатне материнство, сурогатна мама, нотаріальний договір, нотаріальне посвідчення, законодавче регулювання.

Постановка наукової проблеми та їі значення. Станом на сьогодні наше суспільство прогресує у всіх можливих аспектах його розвитку. Якщо ще до недавніх пір такі словосполучення як «сурогатне материнство», «сурогатна мама», «договір про надання послуг сурогатного материнства» викликали певну стурбованість та в деякій мірі хвилювання, а чи навіть здивування, здавались чимось далеким, то уже станом на сьогодні вони все сміливіше вливаються у повсякденне життя українців та набувають все більшої популярності. В силу недостатньої урегульованості законом сфери надання послуг сурогатного материнства, дослідження теоретичних та практичних аспектів нотаріального посвідчення договорів про надання послуг сурогатного материнства набувають все більшої

(С) ЛевчукЮ., 2019 
актуальності. На жаль, через відсутність чіткого законодавчого врегулювання, станом на сьогодні сфера сурогатного материнства в Україні набула статусу «дозволено тому, що не заборонено».

3 однієї сторони, сурогатний процес несе в собі не що інше, як, без сумніву, позитив для потенційних генетичних батьків, тобто, тих осіб, які внаслідок певних життєвих обставин позбавлені можливості стати батьками природнім шляхом. 3 іншої сторони, це кропітка праця, можливо, й в більшій мірі альтруїзм сурогатної матері, тобто, тієї особи, що бере на себе мужність та обов'язок виносити генетично чужу їй дитину, а потім віддати її потенційним генетичним батькам.

Таким чином, сурогатне материнство - сучасний тренд, що прийшов в Україну, та уже встиг укорінитися в її суспільному житті. Це позитивно чи, більшою мірою, негативно? Як врегульовано законом сферу надання послуг сурогатного материнства в Україні? Що становить собою договір про надання послуг сурогатного материнства?

Аби дати відповідь на ці питання необхідно, на наш погляд, спершу звернутись до короткого екскурсу історії виникнення сурогатного материнства як явища, визначити поняття сурогатного материнства як такого на сучасному етапі розвитку суспільних відносин в Україні, а також, власне, правові та теоретичні аспекти його регулювання у нашій державі.

Тому метою нашої статті $\epsilon$ окреслення історії виникнення та розвитку сурогатного материнства, визначення поняття сурогатного материнства, аналіз наявного законодавчого базису, теоретичного та практичного аспектів, що регулюють сурогатний процес в нашій державі, зокрема, процес укладення договорів про надання послуг сурогатного материнства, а також напрацювання певних висновків та наукових положень щодо ролі і місця договору про надання послуг сурогатного материнства в системі законодавства України.

Аналіз досліджень наукової проблеми. Серед провідних вчених-науковців проблемам інституту сурогатного материнства приділяли увагу як вітчизняні, так і зарубіжні спеціалісти у сфері цивільного та сімейного права, зокрема, В. А. Ватрас, Я. І. Верес, К. А. Гітліна, А. П. Головащук, Н. М. Квіт, Ю. В. Коренга, О. С. Митрякова, А. А. Пестрикова, В. В. Самойлова, Л. Б. Ситдікова, Т. В. Сорокіна та ін.

Виклад основного матеріалу й обгрунтування отриманих результатів дослідження. Перші згадки про сурогатне материнство відносяться до Старого завіту, коли служниця Авраама народила від нього дитину, яку потім передали на виховання дружині Авраама. Далі історія налічує не один випадок, коли дитина, яку народила наложниця чи рабиня від свого господаря, віддавалась на виховання законній дружині цього чоловіка. Таким чином, це були перші кроки людства по боротьбі iз безпліддям. В той же час, наголосимо, що в стародавні часи єдиним способом було народження рабинею саме генетично рідної їй дитини та подальший обов'язок віддати дитину. Перший випадок успішного сурогатного материнства пройшов в Сполучених Штатах Америки, де в 1986 році сурогатна мати виносила і народила повністю генетично чужу їй дитину.

Згадка про репродукційні права $\epsilon$ і в старому радянському сімейному законодавстві, де ч. 2 ст. 56 Кодексу про шлюб та сім'ю визначала, що чоловік, котрий дав письмову згоду на запліднення своєї дружини за допомогою донора, записується батьком народженої нею дитини й не має права оспорювати проведений запис. Практичне використання сурогатного материнства в Україні почалося з 1995 року [1, с. 246].

Справа в тому, що у чинному законодавстві нашої держави відсутнє визначення поняття сурогатного материнства, воно має місце тільки в суспільних відносинах, пов'язаних із сучасними репродуктивними технологіями. Сурогатне материнство має декілька аспектів, зокрема, перший його аспект - медичний - вбачає у процесі сурогатного материнства процес перенесення ембріона, отриманого заплідненням яйцеклітини біологічної матері - дружини спермою біологічного батька чоловіка, в порожнину матки іншої жінки та виношування дитини, яка є біологічно «чужою» для жінки. Якщо перекласти дане твердження на медичну термінологію, то процес сурогатного материнства називають екстракорпоральним заплідненням, що може бути реалізований тільки висококваліфікованими фахівцями даної галузі медицини у спеціальних закладах.

Що стосується правового аспекту визначення та сприйняття сурогатного материнства, то думки вчених-науковців різняться. Т. В. Сорокіна вважає, що під сурогатним материнством слід розуміти процес імплантації, виношування та народження дитини виконавцем (сурогатною матір'ю), яка зачата 3 використанням генетичного матеріалу замовника (замовників), донора чи самої сурогатної матері, на основі договору сурогатного материнства між сурогатною мамою і можливими батьками на оплатній чи безоплатній основі [2, с. 216]. Тобто, ії розуміння сурогатного материнства не розмежовує різновидів сурматеринства: традиційного (за якого сурогатна мама може мати генетичний зв'язок 3 дитиною) та гестаційного (за якого відсутній генетичний зв'язок сурмами 3 
дитиною). Варто одразу наголосити, що традиційне сурогатне материнство чітко заборонено на законодавчому рівні в Україні.

На думку В. В. Самойлової, сурогатне материнство - метод допоміжних репродуктивних технологій, за допомогою якого жінка на підставі взаємної домовленості з особами, що звернулися до неї за наданням вказаної послуги, проходить процедуру імплантації ембріона, створеного в результаті ЕКО, виношує дитину з метою народити та передати ії цим особам. При цьому в дане поняття мають також включатися випадки, коли досягнути мети народити та передати дитину особам, які звернулися за такою послугою, не вдається [3, с. 234].

Для порівняння, у «Юридичному словнику» (США) під сурогатним материнством мають на увазі правовідносини, за яких жінка виношує й народжує дитину для особи чи подружжя, які потім іiі всиновлюють чи беруть під опіку. Національне законодавство не визначає необхідності такої складної процедури для генетичних батьків та встановлює презумпцію батьківства подружжя, що надавало біологічні гамети. Тому й в юридичних колах в Україні найпоширенішим є наступне розуміння: сурогатне материнство - це запліднення генетично сторонньої жінки (без використання іiі біологічного матеріалу), шляхом імплантації або трансплантації ембріона 3 використанням генетичного матеріалу чоловіка та жінки, які перебувають у шлюбі, 3 метою виношування i народження дитини, яка надалі буде визнана такою, що походить від подружжя, на підставі відповідного договору між подружжям та сурогатною матір'ю [4, с. 43]. Тобто, національне право та наука вказують на обов' язковий генетичний зв' язок між батьками та дитиною.

Таким чином, на наш погляд, сурогатне материнство у правовому аспекті- це процес перенесення ембріона / ембріонів, які утворились шляхом використання біологічного матеріалу потенційних батьків та / або потенційного батька чи матері з можливим залученням донора за наявності медичних показів (неможливості виносити та народити дитину особисто потенційними батьками) у організм сурогатної матері за наявності їх добровільного волевиявлення та згоди з метою виношування нею вагітності та народження, як результат, дитини / дітей, які визнаватимуться такими, що походять від потенційних батьків та генетично споріднені хоча б з одним із батьків, відносини між сторонами при цьому безумовно регулюватимуться на підставі відповідного нотаріально посвідченого договору про надання послуг сурогатного материнства на комерційній чи некомерційній основі за домовленістю сторін.

3 наведеного вище визначення можна виділити наступні ознаки сурогатного материнства:

- добровільна згода та волевиявлення сторін процесу на участь в програмі сурогатного материнства, що закріплено у нотаріально посвідченому договорі про надання послуг сурогатного материнства;

- фізіологічна нездатність (внаслідок медичних показів, що підтверджується відповідними висновками медичних установ) стати батьками, зачати, виносити і народити дитину особисто потенційними батьками;

- генетична спорідненість плоду хоча б з одним із потенційних батьків;

- зачаття дитини шляхом екстракорпорального запліднення та специфічна мета сурогатного материнства - виносити та народити дитину та де-юре визнати ії такою, що походить від потенційних батьків.

Українське законодавство в сфері сурогатного материнства, на жаль, не характеризується комплексністю. Втім, окремі норми щодо сурогатного материнства передбачені в Цивільному [5] та Сімейному [6] кодексах України, у Законі України «Основи законодавства України про охорону здоров'я» [7], у Правилах державної реєстрації актів цивільного стану України, затверджених Наказом Міністерства юстиції України від 18 жовтня 2000 р. [8], Порядку застосування допоміжних репродуктивних технологій в Україні, затвердженого Наказом Міністерства охорони здоров'я від 9 вересня 2013 р. [9].

Щодо Цивільного кодексу, то варто констатувати, що у ньому взагалі відсутнє поняття «сурогатне материнство» чи «сурогатний договір». На наш погляд, кодекс можна віднести до такого нормативно-правового акту, що частково стосується питання сурогатного материнства та частково його регулює, адже він покликаний в тому числі регулювати відносини особисті немайнові, засновані на юридичній рівності та вільному волевиявленні їх учасників (ст. 1, ч.1 ЦКУ) [5], до яких ми і відносимо відносини в сфері сурогатного материнства. А серед загальних засад цивільного законодавства кодекс називає свободу договору (ст. 3, ч.1, п. 3 ЦКУ) та деталізує, що сторони мають право укласти договір, який не передбачений актами цивільного законодавства, але відповідає загальним засадам цивільного законодавства (ст. 6, ч.1 ЦКУ). Принцип свободи договору деталізується зокрема, і в статті 627 ЦК. Наше цивільне законодавство під договором розуміє 
домовленість двох або більше сторін, спрямованих на встановлення, зміну або припинення цивільних прав та обов'язків (ст. 626, ч. 1 ЦКУ) [5].

Цивільний кодекс у ст. 284 регламентує таке особисте немайнове право особи як право на надання особі медичної допомоги, на вибір лікаря та вибір методів лікування, на наш погляд, це стосується і права особи на здійснення сурогатного материнства.

Таким чином, якщо вести мову про основні аспекти регулювання сурогатного материнства в Україні цивільним законодавством, то варто констатувати, що регулювання сурогату має цивільноправовий характер. Сурогатне материнство покликане регулювати відносини між біологічними батьками та сурогатною матір'ю, зокрема шляхом укладення цивільно-правового договору, істотні умови, оплатність / безоплатність, відповідальність за порушення та особливості укладення якого i відносяться до сфери регулювання цивільного права в контексті положень ЦКУ про договір та зобов' язальне право.

Щодо сімейного законодавства, то у ньому теж відсутнє поняття «сурогатне материнство» чи «сурогатний договір». Втім, у ньому присутнє уже наближене максимально до проблематики сурогатного материнства поняття допоміжних репродуктивних технологій та чітке визначення походження дитини. Зокрема, ст. 123 СКУ в частині 2 регламентує факт визнання подружжя батьками дитини, зачатої цим подружжям та народженої в результаті застосування допоміжних репродуктивних технологій іншою жінкою, в організм якої і було перенесено ембріон. Звідси стає очевидним, що поняття «інша жінка» у даній статті СК означає собою поняття «сурогатна матір».

Сімейний кодекс в тому числі встановлює право особи на сім’ю, право жінки на материнство та право чоловіка на батьківство. Сурогатне материнство в даному випадку може виступати механізмом реалізації жінкою та чоловіком вище перерахованих прав, тому власне, відносини, що виникають із процесу сурогатного материнства, мають і сімейно-правову природу.

У Законі України «Основи законодавства України про охорону здоров' я» у ст. 57 йде мова про те, що материнство в Україні заохочується та охороняється державою. 3 метою охорони здоров'я жінки їй надається право самій вирішувати питання про материнство [7].

На наш погляд, найбільш конкретним на даному етапі розвитку українського сурогатного законодавства $\epsilon$ Порядок застосування допоміжних репродуктивних технологій в Україні, затверджений Наказом Міністерства охорони здоров’я № 787 від 9 вересня 2013 р. [9]. При цьому даний нормативно-правовий акт не $є$ профільним конкретно для нотаріуса як суб'єкта, що уповноважений законом посвідчити договір про надання послуг сурогатного материнства чи договір про виношування дитини, адже прийнятий Міністерством охорони здоров'я та покликаний врегулювати саме питання медичного характеру, зокрема регулює відносини між пацієнтами (жінками, чоловіками) та закладами охорони здоров'я, які забезпечують застосування методик допоміжних репродуктивних технологій. Втім, це єдиний акт, в якому регламентовано ключові, хоча i мінімально, основи регулювання сурогатного материнства в Україні.

Порядок не містить визначення чи тлумачення поняття сурогатного материнства, на жаль. Втім, чітко регламентує умови, за яких сурогатне материнство може бути застосовано в будь-якому конкретному випадку. До них відносять:

- наявність медичних показань до сурогатного материнства, зокрема відсутність матки (вроджена або набута); деформація порожнини або шийки матки при вроджених вадах розвитку або внаслідок хірургічних втручань, доброякісних пухлин, при яких неможливе виношування вагітності; структурно-морфологічні або анатомічні зміни ендометрія, що призводять до втрати рецептивності, синехії порожнини матки, які не піддаються лікуванню; тяжкі соматичні захворювання, при яких виношування вагітності загрожує подальшому здоров'ю або життю реципієнта, але які не впливають на здоров'я майбутньої дитини; невдалі повторні спроби застосування допоміжних репродуктивних технологій (4 і більше разів) при неодноразовому отриманні ембріонів високої якості, перенесення яких не приводило до настання вагітності.

- документи, необхідні для проведення сурогатного материнства;

- подружжя (або один 3 майбутніх батьків), в інтересах якого здійснюється СМ, повинно (повинен) мати генетичний зв' язок з дитиною;

- сурогатна мати не повинна мати безпосередній генетичний зв'язок 3 дитиною. Дозволяється виношування вагітності близькими родичами майбутніх батьків (мати, сестра, двоюрідна сестра тощо) [9].

Щодо переліку необхідних, встановлених цим Порядком на законодавчому рівні, документів, то варто зазначити, що на наш погляд, це єдине джерело, яким ми зобов’язані на даному етапі 
розвитку відносин в сфері законодавчого регулювання сурогатного материнства, керуватись при нотаріальному посвідченні договорів про надання послуг сурогатного материнства.

Зокрема, пункт 6.10 Порядку встановлює необхідний перелік документів для сурогатної матері, серед яких: iii заява на участь в програмі сурогатного материнства, копія паспорту, копія свідоцтва про шлюб чи копія свідоцтва про розірвання шлюбу (рішення суду про розірвання шлюбу),

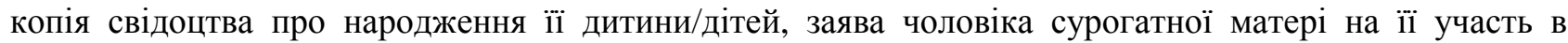
програмі сурогатного материнства [9].

Звідси вбачається за необхідне витребувати дані документи при посвідченні договору про надання послуг сурогатного материнства. При цьому, на наш погляд, та виходячи із практики посвідчення таких договорів, від сурогатної матері доцільніше вимагати нотаріально посвідчену заяву-згоду на ii участь в програмі сурогатного із зазначенням конкретно погоджених батьківзамовників сурогатної програми; паспорт доцільно перевіряти у базі даних викрадених або втрачених паспортів Міністерства внутрішніх справ 3 метою уникнення потенційних негативних наслідків. Якщо сурогатна мати в шлюбі, iii чоловік повинен надати нотаріально посвідчену заяву-згоду на участь його дружини у програмі сурогатного материнства. Якщо сурогатна мати не в шлюбі, то доцільно вимагати від неї такого ж роду нотаріально посвідчену заяву про те, що вона не перебуває в шлюбі чи у фактичних шлюбних відносинах. При цьому нотаріус керується інформацією 3 Державного реєстру актів цивільного стану не тільки для встановлення факту шлюбних/нешлюбних відносин, а й факту наявності власної дитини/дітей в сурогатної матері, оскільки серед встановлених законом вимог для участі у програмі $є$ наявність власної здорової дитини у потенційної сурогатної матері.

Таким чином, перелік даних документів повністю співставний із встановленими вимогами для набуття статусу сурогатної матері та можливості участі в програмі сурогатного материнства. Порядок регламентує, що сурогатною матір'ю може бути повнолітня дієздатна жінка за умови наявності власної здорової дитини, добровільної письмово оформленої заяви за формою, наведеною в додатку 17 до цього Порядку, а також за відсутності медичних протипоказань [9].

Щодо переліку необхідних для батьків-замовників сурогатної програми документів, то серед них Порядок називає їхню заяву щодо застосування методу допоміжних репродуктивних технологій, яка, на наш погляд, теж повинна бути нотаріальною та містити інформацію 3 приводу наявності медичних показань для застосування сурогатного материнства; копії паспортів та копія свідоцтва про шлюб. Паспорти нотаріус перевіряє за аналогією у базі даних викрадених або втрачених паспортів Міністерства внутрішніх справ 3 метою уникнення потенційних негативних наслідків; факт шлюбу подружжя нотаріус перевіряє за даними Державного реєстру актів цивільного стану.

Порядок встановлює необхідну наявність нотаріального посвідченого договору про надання послуг сурогатного материнства між батьками-замовниками сурогатної програми та сурогатною матір'ю для початку проведення процедури сурогатного материнства.

На жаль, це єдиний підзаконний акт, в якому законодавчо встановлена обов’язкова нотаріальна форма такого договору.

Пункт 11 глави 1 Розділу III Правил державної реєстрації актів цивільного стану України [8] прописує наступне: «У разі народження дитини жінкою, якій в організм було перенесено ембріон людини, зачатий подружжям у результаті застосування допоміжних репродуктивних технологій, державна реєстрація народження проводиться за заявою подружжя, яке дало згоду на таке перенесення. У цьому разі одночасно з документом, що підтверджує факт народження дитини цією жінкою, подається заява про їі згоду на запис подружжя батьками дитини, справжність підпису на якій має бути нотаріально засвідченою, а також довідка про генетичну спорідненість батьків / матері чи батька/ $з$ плодом. При цьому в графі «Для відміток» актового запису про народження робиться такий запис: «Матір'ю дитини згідно з медичним свідоцтвом про народження є громадянка (прізвище, власне ім'я, по батькові)», а також зазначаються найменування закладу (установи), що видав(ла) довідку, дата їі видачі та номер, дані нотаріуса (прізвище та ініціали, нотаріальний округ чи державна нотаріальна контора), дата та за яким реєстровим номером засвідчено справжність підпису жінки на заяві про іiі згоду на запис подружжя батьками дитини».

Таким чином, для реєстрації батьків-замовників сурогатної програми батьками дитини окрім їх заяви про реєстрацію народження, вони повинні надати органам РАЦС нотаріально посвідчену заяву-згоду сурогатної матері на запис батьками народженої нею дитини, згідно 3 медичним свідоцтвом про народження, потенційних батьків-замовників сурогатної програми та довідку про генетичну спорідненість дитини хоча б з одним із них. 
Висновки. На наш погляд, на даному етапі розвитку суспільних відносин договір про надання послуг сурогатного материнства - єдиний акт, в якому необхідно передбачити усі можливі варіанти розвитку подій з метою забезпечення безспірності подальших відносин. Тому у ньому необхідно обов'язково прописувати чіткий предмет договору та чіткий розмір компенсацій сурогатній матері за виношування та народження нею дитини (окрім випадків безоплатності такого договору за бажанням сторін); права та обов'язки сторін договору; відповідальність і батьків-замовників сурогатної програми, і сурогатної матері, в тому числі матеріальна відповідальність; дії батьків-замовників в разі народження дитини 3 генетичними вадами, в тому числі і якщо буде доведено, що це сталось внаслідок недобросовісної поведінки сурогатної матері; кількість ембріонів та випадки багатоплідної вагітності; вибір медичного закладу для проведення програми, спостереження вагітності та пологів, вибір місця проживання сурогатної матері; порядок компенсацій при необхідності переривання вагітності, викидні, народженні мертвої дитини; порядок відшкодування витрат на медичне обслуговування, харчування, спеціальний одяг, проживання сурогатної матері в період виношування дитини, пологів та післяпологовий період; дії щодо новонародженої дитини у випадку смерті обох батьків замовників сурогатної програми; виплата компенсацій сурогатної матері у випадку ії смерті під час пологів; порядок припинення договору та порядок односторонньої відмови від договору.

Безперечно, нагальним є врегулювання процедури нотаріального посвідчення договору про надання послуг сурогатного материнства на рівні профільного закону з чітким встановленням вимог до його учасників та, власне, й самого договору.

В силу відсутності в нашому законодавстві детальної регламентації процедури сурогатного материнства та профільного закону, залишається плекати надію на нотаріально посвідчений договір між батьками-замовниками сурогатної програми та сурогатною матір'ю, як на такий, що не допустить виникнення конфліктних та спірних ситуацій та полегшить процес врегулювання відносин між потенційними батьками та сурогатною матір'ю.

\section{Джерела та література}

1. Марко Я. Р. Право на сурогатне материнство: проблеми розширеного розуміння / Я. Р. Марко [Електронний ресурс]. - Режим доступу: 37323/1/37_245-249.pdf

2. Сорокина Т. В. Суррогатное материнство: понятие и критерии его определения / Т. В. Сорокина // Вестник Волгоградского государственного университета. Серия 5: Юриспруденция. - 2010. - Т. 5. № 2 (13). - С. 216.

3. Самойлова В. В. Суррогатное материнство как правовой институт / В. В. Самойлова // Теория и практика общественного развития. - 2014. - № 4. - С. 234-236.

4. Таланов Ю. Ю. Сурогатне материнство: морально-правові аспекти / Ю. Ю. Таланов // Збірник наукових праць Харківського національного педагогічного університету імені Г. С. Сковороди. "Право". - 2012. - Вип. 19. - С. 42-47.

5. Цивільний кодекс України від 16.01.2003 p. [Електронний ресурс]. - Режим доступу: www.rada.gov.ua.

6. Сімейний кодекс України від 10.01.2002 p. [Електронний ресурс]. - Режим доступу: www.rada.gov.ua.

7. Закон України «Основи законодавства України про охорону здоров'я» від 19.11 .1992 р. [Електронний ресурс]. - Режим доступу: www.rada.gov.ua.

8. Правила державної реєстрації актів цивільного стану України, затверджених Наказом Міністерства юстиції України № 52/5 від 18 жовтня 2000 р. [Електронний ресурс]. - Режим доступу: www.rada.gov.ua.

9. Порядок застосування допоміжних репродуктивних технологій в Україні, затвердженого Наказом Міністерства охорони здоров’я № 787 від 9 вересня 2013 р. [Електронний ресурс]. - Режим доступу: www.rada.gov.ua.

Левчук Ю. Теоретические и практические аспекты нотариального удостоверения договора о предоставлении услуг суррогатного материнства. В статье освещены основные аспекты нотариального удостоверения договоров о предоставлении услуг суррогатного материнства в 
практической плоскости, а также проанализированы теоретические основы законодательного регулирования процесса заключения договора о предоставлении услуг суррогатного материнства в Украине. Регулирование услуг суррогатного материнства имеет гражданско-правовой характер и осуществляется путем заключения гражданско-правового договора между биологическими родителями и суррогатной матерью. В договоре о предоставлении услуг суррогатного материнства необходимо предусмотреть все возможные варианты развития событий с целью обеспечения бесспорности дальнейших отношений. Поэтому в нем необходимо обязательно прописывать четкий предмет договора и четкий размер компенсаций суррогатной матери за вынашивание и рождение ею ребенка (кроме случаев бесплатности такого договора по желанию сторон); права, обязанности и ответственность сторон договора; порядок прекращения, отказа от договор; другие существенные условия. Актуальным является урегулирование процедуры нотариального удостоверения договора о предоставлении услуг суррогатного материнства на уровне профильного закона с четким установлением требований к его участникам и самому договору. Из-за отсутствия в законодательстве Украины детальной регламентации процедуры суррогатного материнства решение юридических проблем возможно через нотариально удостоверенный договор между родителями-заказчиками суррогатной программы и суррогатной матерью, поскольку этот способ не допустит возникновения конфликтных и спорных ситуаций и облегчит процесс урегулирования отношений между потенциальными родителями и суррогатной матерью.

Ключевые слова: суррогатное материнство, суррогатная мама, нотариальный договор, нотариальное удостоверение, законодательное регулирование.

Levchuk Yu. Theoretical and Practical Aspects of the Notarial Dedication of the Agreement on Donation of the Services of Surrogate Motherhood. The article attempts to highlight the main aspects of surrogacy maternity contracts notarization in the practical field, as well as to analyze the theoretical basis of legislative regulation of the process of concluding a contract for the provision of surrogacy services in Ukraine. The regulation of a surrogacy maternity has a civil nature. Surrogacy is called to regulate the relationship between the biological parents and the surrogate mother, in particular by concluding a civil contract. The agreement on donation of the services of surrogate motherhood must provide for all possible developments in order to ensure the continuity of future relationships. Therefore, it is necessary to prescribe in it a precise subject of the agreement and a certain amount of compensation of the surrogate mother for the gestation and birth of her child (except for cases where such a contract is free of charge at the request of the parties); the rights, obligations and responsibilities of the parties of the agreement; the procedure for termination, cancellation of the contract, other significant conditions. It is urgent to regulate the procedure of notarization of the contract for the provision of surrogacy services at the level of the relevant law with a clear establishment of requirements for its participants and, in fact, the contract itself. Because of the lack of detailed regulation of the surrogacy procedure and the relevant law in our legislation, it remains to hope for a notarized agreement between the parents-customers of the surrogate program and the surrogate mother, as one that will prevent conflicts and disputes and facilitate the settlement process the relationship between potential parents and the surrogate mother.

Key words: surrogate motherhood, surrogate mother, notarial agreement, notarized dedication, legislative regulation. 